\title{
Does Shareholder Proxy Access Improve Firm Value? Evidence from the Business Roundtable Challenge
}

\section{Citation}

Becker, Bo, Guhan Subramanian, and Daniel B. Bergstresser. "Does Shareholder Proxy Access Improve Firm Value? Evidence from the Business Roundtable Challenge." Journal of Law \& Economics (forthcoming).

\section{Permanent link}

http://nrs.harvard.edu/urn-3:HUL.InstRepos:9932210

\section{Terms of Use}

This article was downloaded from Harvard University's DASH repository, and is made available under the terms and conditions applicable to Open Access Policy Articles, as set forth at http:// nrs.harvard.edu/urn-3:HUL.InstRepos:dash.current.terms-of-use\#OAP

\section{Share Your Story}

The Harvard community has made this article openly available. Please share how this access benefits you. Submit a story. 
H A R V A R D

Does Shareholder Proxy Access Improve Firm Value? Evidence from the Business Roundtable Challenge

Bo Becker

Daniel Bergstresser

Guhan Subramanian

\section{Working Paper}

11-052

January 19, 2012 


\title{
Does Shareholder Proxy Access Improve Firm Value? Evidence from the Business Roundtable Challenge
}

\author{
Bo Becker, Daniel Bergstresser \& Guhan Subramanian*
}

January 2012

\begin{abstract}
We use the Business Roundtable's challenge to the SEC's 2010 proxy access rule as a natural experiment to measure the value of shareholder proxy access. We find that firms that would have been most vulnerable to proxy access, as measured by institutional ownership and activist institutional ownership in particular, lost value on October 4, 2010, when the SEC unexpectedly announced that it would delay implementation of the Rule in response to the Business Roundtable challenge. We also examine intra-day returns and find that the value loss occurred just after the SEC's announcement on October 4. We find similar results on July 22, 2011, when the D.C. Circuit ruled in favor of the Business Roundtable. These findings are consistent with the view that financial markets placed a positive value on shareholder access, as implemented in the SEC’s 2010 Rule.
\end{abstract}

JEL codes: G14, G32, G34, G38

\footnotetext{
${ }^{*}$ Harvard Business School and the National Bureau of Economic Research; Harvard Business School; and Harvard Business School and Harvard Law School, respectively. We are grateful for comments and suggestions from Renee Adams, Lucian Bebchuk, John Coates, Jesse Fried, Robin Greenwood, Joe Grundfest, Marcel Kahan, Don Langevoort, Nell Minow, Ed Rock, Mark Roe, Andrei Shleifer, Robert Thomas, Joshua White and seminar participants at Brandeis University, Georgetown Law School, Harvard Law School, Harvard Business School, NYU Law School, and the Stockholm School of Economics. We thank Chris Allen and Sarah Eriksen for excellent research assistance.
} 


\section{Does Shareholder Proxy Access Improve Firm Value? Evidence from the Business Roundtable Challenge}

Shareholder access to the company's proxy statement has been one of the most heated if not the most heated - topics in corporate governance over the past decade. ${ }^{1}$ Opponents of proxy access argue that it would shift a dangerous amount of power to certain kinds of shareholders (for example, union pension funds) who could pursue objectives counter to shareholder value maximization (e.g., Bainbridge 2003). They also argue that high-quality directors may be less willing to serve on boards if they must face competition from shareholdersponsored candidates (e.g., Lipton and Rosenblum 2003). Proponents of shareholder access argue that competition in the director election process is desirable, and that giving institutional investors more influence in the director election process will likely benefit all shareholders (Bebchuk 2003, Bebchuk and Hirst 2010).

We use the Business Roundtable's challenge to the proxy access rule as a natural experiment to measure the value of shareholder proxy access. On August 25, 2010, under authority provided by Section 971 of the Dodd-Frank Wall Street Reform and Consumer Protection Act, the SEC enacted a shareholder proxy access rule (the "Rule"). This Rule was intended to go into effect on November 15, 2010. On September 29, however, the Business Roundtable filed a petition in the D.C. Circuit Court of Appeals challenging the new Rule, alleging that it was arbitrary and capricious, exceeded the SEC's authority, and would reduce overall shareholder wealth. In a move that surprised most observers, on October 4 the SEC announced that it would delay implementation of the new Rule until the Business Roundtable

\footnotetext{
${ }^{1}$ See, e.g., Business Roundtable and U.S. Chamber of Commerce v. U.S. Securities \& Exchange Commission, Complaint filed Sept. 29, 2010 at 2 ("Few issues in corporate governance have generated more disagreement or stronger passions.").
} 
challenge was resolved. On July 22, 2011, the U.S. Court of Appeals for the D.C. Circuit struck down the Rule under the Administrative Procedure Act, accepting the Business Roundtable’s argument that the SEC was insufficiently deliberate and rational in adopting the Rule. In September 2011, the SEC announced that it would not appeal the D.C. Circuit's ruling, but rather would permit shareholders to pursue access on a company-by-company basis.

The Business Roundtable's challenge to the SEC's proxy access rule provides the basis for an event study. If shareholder access increases shareholder value, then companies that would have been most exposed to the new Rule should decline in value, relative to companies that would have been more insulated from the Rule, in response to the SEC's unexpected stay on proxy access (October 4, 2010) and the (arguably) unexpected decision by the D.C. Circuit to invalidate proxy access (July 22, 2011). If instead shareholder access decreases shareholder value, then companies that would have been most exposed to the Rule should increase in value, relative to those what would have been more insulated, on these dates. This natural experiment allows a rough quantification of the value of shareholder proxy access. In addition, the experiment allows testing of hypotheses about board influence. If there is heterogeneity across firms in the value of shareholder influence through the board of directors, or across different types of shareholders in their ability to improve the value of firms, our natural experiment provides an opportunity to quantify those differences.

We use measures of institutional ownership, and activist institutional ownership ${ }^{2}$ in particular, as a proxy for vulnerability to the Rule. Using a 1-day event window around October

\footnotetext{
${ }^{2}$ By activist hedge fund, we refer to hedge funds with a history of corporate activism and intervention (see Greenwood and Schor 2009 and Brav, Jiang, Partnoy, and Thomas 2008). We discuss the motivation for this in more detail below.
} 
$4,2010,{ }^{3}$ we find that share prices of companies that would have been most vulnerable to the Rule declined significantly compared to share prices of companies that would have been most insulated from the Rule. Specifically, we find a 44 basis point spread between firms with high institutional ownership and firms with low institutional ownership for that day's returns. The pattern of lower returns for firms with higher institutional ownership holds true for equalweighted excess return portfolios (37 basis point differential), as well as portfolios based on activist ownership (43 basis point differential). All three of these estimates are statistically significant. In a regression setting, we confirm that institutional ownership, and especially activist institutional ownership, was correlated with negative returns on October 4. For July 22, 2011, we find results that are directionally similar to the October 4, 2010 results, slightly smaller in magnitude and statistically significant. Taken as a whole, these findings are consistent with the view that financial markets placed a positive value on shareholder access, as implemented in the SEC’s August 2010 Rule. Presumably, the stock market perceived the stay as a reduced likelihood of proxy access in the short run as well as in the long run, perhaps seeing the stay as indication of the SEC's own perception of their ability to defend the rule in court.

We also use intra-day data on October 4 to determine whether our overall results can be attributed to shareholder proxy access. We find that virtually all of the observed activist effect comes after the 12:21 pm announcement of the SEC stay - a period during which the overall market hardly moved. The value loss in activist-held firms appears to have accelerated substantially after a Bloomberg news story about the SEC stay appeared at 3:20 pm. These intraday results suggest that the relative drop in the market value of equity for firms with large

\footnotetext{
${ }^{3}$ Using a one-day event window to study proxy access is tantamount to focusing on the market's short term view of the announcement's value effect. Unfortunately, the event study methodology is much less suitable for identifying the market's long-term views (since long term stock returns are more variable than short term stock returns).
} 
activist ownership can be attributed to the SEC's announcement delaying shareholder proxy access. $^{4}$

The paper proceeds in six sections. Section 1 summarizes the evolution of shareholder access in the U.S. Section 2 reviews the existing related literature on proxy access and corporate governance more generally. Section 3 explains our empirical strategy. Section 4 describes our data and methodology. Section 5 presents our results, and Section 6 discusses potential interpretations. Section 7 concludes.

\section{Background: Proxy access and boards of directors in the United States}

The corporate law of every U.S. jurisdiction requires that corporations hold an annual meeting to elect directors. In this election, the company will invariably nominate exactly the number of candidates to fill the available seats - for example, seven candidates for seven seats. Shareholders of the corporation have the right to nominate their own candidates to the board. Any shareholder can propose a nominee to the board's nominating committee, but if the board refuses to put the shareholder's candidate on the company's slate (which is by far the more common outcome), the shareholder would have to engage in a time-consuming and expensive process in order to get their candidate seated. Specifically, a shareholder who wants to nominate one or more candidates would have to file Schedule 14A with the SEC, hire a proxy solicitor, and often engage in an expensive public campaign to support their nominee or nominees. These

\footnotetext{
${ }^{4}$ The intra-day findings respond to critics of an earlier version of our paper, who expressed skepticism about the validity of event study methodology in general and the causal inferences that can be drawn from such a methodology. See, e.g., David Marcus, The Proxy Access Problem, The DeAL (Nov. 24, 2010) ("[R]eaders with little understanding of and less confidence in the black art of regression analysis may well be skeptical of a paper that claims to be able to assign a value measured in basis points to a single amorphous factor on a single trading day among the dozens that affect the value of stocks.”).
} 
expenses are only reimbursed if the shareholder gains control of the board. ${ }^{5}$ Moreover, the shareholder must share the benefits of any improvement in corporate performance pro rata with the other shareholders. As a result of these obstacles, contested director elections outside the context of a hostile takeover bid have been exceedingly rare in corporate America (Bebchuk 2003). ${ }^{6}$

Against this backdrop, many commentators have viewed shareholder access to the company’s proxy statement as an essential step to make director elections more meaningful, and, by extension, to improve overall corporate governance. After decades of discussion, ${ }^{7}$ and not coincidentally in the wake of corporate scandals at Enron, Worldcom, and other large U.S. public companies, the SEC proposed a shareholder access rule in October 2003. Under the 2003 rule, shareholders would gain the right to place one or more nominees on the company's proxy statement after one of two trigger events had occurred: (1) “withhold” votes of more than 35\% of votes had been cast for one or more directors; or (2) a majority vote for a 14a-8 shareholder access proposal, proposed by a shareholder or shareholder group that had held at least $1 \%$ of the company's shares for at least one year. The Business Roundtable and other groups representing director and management interests engaged in a lobbying effort against the proposed Rule. By early 2005, the SEC issued a series of no-action letters permitting companies to omit shareholder proposals based on the proposed rule, effectively withdrawing its proposal.

\footnotetext{
${ }^{5}$ For the classic statement of this rule, see Rosenfeld v. Fairchild Engine \& Airplane Corp., 128 N.E. 2 d 291 (N.Y. 1955)

${ }^{6}$ In July 2007, the SEC promulgated its long-awaited “eProxy Rules,” which allow insurgents to post their proxy materials on-line and simply mail shareholders a "Notice of Internet Availability of Proxy Materials.” In theory, eProxy rules should reduce the costs of proxy solicitation and increase the number of contested director elections. However, the early empirical evidence suggests that the number of contested director elections did not increase substantially in the 2009 or 2010 proxy seasons.

${ }^{7}$ See Proposed Rule, 74 Fed. Reg. at 29,029 n. 73 (June 18, 2009) (noting that the Commission first considered proxy access in 1942).
} 
In 2006, the American Federation of State, County, and Municipal Employees (AFSCME) submitted a shareholder proposal to American International Group (AIG) to amend AIG's bylaws so that a 3\% shareholder could place one nominee in AIG's proxy materials - in effect, trying to do at AIG what the SEC's proposed Rule 14a-11 had tried to do more generally. Surprising many commentators, the Second Circuit Court of Appeals held that this proposal was not excludable under the Rule 14a-8(i)(8) exclusion, which at the time permitted companies to exclude proposals “relat[ing] to an election for membership on the company's board of directors." The court found that the proposal related to board elections broadly, and not to "an election” of directors. ${ }^{8}$ The holding seemed to open up the possibility of proxy access on a company-by-company basis. But in December 2007, the SEC amended the Rule 14a-8(i)(8) exclusion to permit corporations to exclude proposals "relating to an election for membership on the company's board” or relating to "a procedure for such nomination or election.” This amendment was intended to reverse the Second Circuit's holding in AFSCME v. AIG.

Shareholder proxy access remained dormant until May 2009, when the SEC returned to the issue with a new shareholder access proposal. The SEC explained: "The nation and the markets have recently experienced, and remain in the midst of, one of the most serious crises of the past century. This crisis has led many to raise serious concerns about the accountability and responsiveness of some companies and boards of directors to the interests of shareholders, and has resulted in a loss of investor confidence." "ำ Under the proposed Rule 14a-11, a shareholder or shareholder group that owned more than $1 \%$ of a large U.S. public company (defined as market capitalization greater than $\$ 700$ million), more than 3\% of a midsize public company (market capitalization $\$ 75-\$ 700$ million), or more than $5 \%$ of a small public company (market

\footnotetext{
${ }^{8}$ AFSCME v. AIG, 462 F.3d 121 (2 ${ }^{\text {nd }}$ Cir. 2006).

${ }^{9}$ Securities and Exchange Commission Proposed Rule Facilitating Shareholder Director Nominations (June 10, 2009).
} 
capitalization less than $\$ 75$ million) would have the ability to place nominees on the company's proxy statement for up to one-quarter of the total board seats.

In an effort to preempt or at least shape the SEC's consideration of shareholder access, Delaware amended its corporate code to confirm that shareholders could amend the company's bylaws to permit proxy access. Section 112 of the Delaware General Corporation Law, enacted in May 2009, provides that: "The bylaws may provide that if the corporation solicits proxies with respect to an election of directors, it may be required ... to include in its proxy solicitation materials ... 1 or more individuals nominated by a stockholder.” Section 112 reflects one application of the Delaware Supreme Court's holding in CA v. AFSCME, ${ }^{10}$ handed down in July 2008, which permits shareholders to regulate procedural aspects of corporate governance (e.g., how decisions are made) but not substantive aspects, which are left to the board. Thus Section 112 confirmed the shareholders' right to opt-in to proxy access (a so-called "voluntary proxy access regime”).

In July 2010, the U.S. Congress passed the Dodd-Frank Wall Street Reform and Consumer Protection Act. Notwithstanding Delaware’s efforts to preempt federal action, Section 971 of the Act amended Section 14(a) of the Securities Exchange Act to provide the SEC explicit authority to adopt proxy access rules. By confirming that the SEC had the authority to issue shareholder access rules and signaling Congress’s support for such rules, Section 971 made shareholder proxy access inevitable, according to most observers.

On August 25, 2010, by a 3-2 vote, the SEC announced the adoption of a final Rule 14a11, mandating proxy access at all U.S. public companies. Any shareholder or shareholder group that held more than $3 \%$ of a U.S. public company's shares for more than three years would be eligible to nominate candidates for up to $25 \%$ of the company's board seats. The new Rule 14a-

\footnotetext{
${ }^{10} 953$ A.2d 227 (Del. 2008).
} 
11 was planned to go in to effect on November 15, 2010, well in time for the April/May 2011 proxy season. $^{11}$

On September 29, the Business Roundtable, along with the U.S. Chamber of Commerce, filed a complaint in the D.C. Circuit Court of Appeals, alleging that the SEC's proxy access rules were unlawful under U.S. securities laws and “arbitrary and capricious."12 The Business Roundtable complaint also asserted - but did not explain - that the SEC's proxy rules “do not promote efficiency, competition, and capital formation."13 The complaint was widelyanticipated by the marketplace based on public statements, including in the comment letters submitted by these two groups to the SEC on the proxy access proposal. Nevertheless, Congress's authorization to the SEC under Section 971 of the Dodd-Frank was intended to largely shut down this kind of challenge; perhaps as a result, the filing of the Business Roundtable complaint did not attract significant media attention.

However, on October 4, the SEC unexpectedly announced that it would stay implementation of Rule 14a-11, pending resolution of the Business Roundtable litigation in the D.C. Circuit. The SEC explained: “Among other things, a stay avoids potentially unnecessary costs, regulatory uncertainty, and disruption that could occur if the rules were to become effective during the pendency of a challenge to their validity." ${ }^{14}$ News accounts noted that the

\footnotetext{
${ }^{11}$ The three year rule excluded many investors with shorter holding periods. However, the rule would have allowed investors with two year holdings, for example, to qualify relatively soon. Cella (2011) shows that activist investors have longer holding periods than other investors in the US.

${ }^{12}$ For ease of exposition we refer to this litigation as the "Business Roundtable complaint" or the "Business Roundtable challenge" hereinafter.

${ }^{13}$ Business Roundtable and U.S. Chamber of Commerce v. U.S. Securities \& Exchange Commission, Complaint filed Sept. 29, 2010 at 2.

${ }^{14}$ In the Matter of the Motion of the Business Roundtable and the U.S. Chamber of Commerce for Stay of Effect of Commission’s Facilitating Shareholder Director Nomination Rules, File No. S7-10-09 (Oct. 4, 2010).
} 
SEC's announcement was a surprise. ${ }^{15}$ Commentators also noted that the SEC's stay meant that proxy access rules would not go into effect for the 2011 proxy season. ${ }^{16}$

On July 22, 2011, the U.S. Court of Appeals for the D.C. Circuit struck down Rule 14a11 under the Administrative Procedure Act. The D.C. Circuit accepted the Business Roundtable's argument that the SEC's process in considering and adopting the new Rule was insufficiently deliberate and rational. ${ }^{17}$

In September 2011, the SEC announced that it would not appeal the D.C. Circuit’s ruling, but instead would re-instate its amendments to Rule 14a-8, which would allow shareholders to vote on a resolution recommending or requiring the inclusion of shareholder-sponsored board candidaets in the next year's corporate proxy statement. The SEC thus moved away from comprehensive proxy access to a two-step, company-by-company approach. Shareholders at several major companies, including Bank of America, Goldman Sachs, Hewlett-Packard, Sprint Nextel, and Wells Fargo, have proposed proxy access resolutions for the 2012 proxy season. ${ }^{18}$

\section{Literature}

The delegation of control over firms to professional managers is a defining feature of modern capitalism (see Berle and Means 1932), and one that raises the possibility of agency problems. Estimating the economic impact of boards and board structure on shareholder wealth has been difficult because of econometric identification challenges. Hermalin and Weisbach (1998) point out that one reason that much of the corporate governance literature finds weak

\footnotetext{
${ }^{15}$ See, e.g., Wachtell, Lipton, Rosen \& Katz memorandum to clients (Oct. 5, 2010), SEC Stays Shareholder Access For Now (noting “unexpected development").

${ }^{16}$ See, e.g., Wachtell memo (Oct. 5, 2010); Jesse Westbrook, SEC Delays Proxy-Access Rules Amid Legal Challenge, BLOOMBERG (Oct. 4, 2010).

${ }^{17}$ Business Roundtable and Chamber of Commerce v. SEC, 647 F.3d 1144 (D.C. Cir. 2011).

${ }^{18}$ Jason Zweig, Will New Tools Help Small Shareholders Topple Giants?, WALL STREET JOURNAL (Jan. 7, 2012).
} 
correlations between board characteristics and firm performance may be that board characteristics are endogenous, i.e. across firms, board characteristics are likely not assigned at random. This makes the effect of any board characteristic (e.g., the presence of outsiders, the number of directors) impossible to identify based only on the observed correlation between that characteristic and firm performance.

Shareholder access to the company's proxy statement is one specific dimension of corporate governance that has been heavily debated over the years. As an illustration, more than 700 different comment letters were submitted to the SEC when proxy access was proposed in 2003; more than 200 different comment letters were submitted during the 2007 rulemaking process; and more than 500 different comment letters were submitted when proxy access was proposed again in 2009. Proponents of shareholder access (e.g., Bebchuk 2003, Bebchuk and Hirst 2010) point out that proxy contests under the existing regime are exceedingly rare, and argue that a meaningful director election process would improve corporate governance. Opponents of shareholder access argue that shareholders already have sufficient voice in the election of directors (e.g., Bainbridge 2010), that shareholder access rules would likely shift too much power to shareholders or shareholders with specific agendas, and that high-quality directors may be less willing to serve on boards if they must face competition from shareholdersponsored candidates (e.g., Lipton and Rosenblum 2003). ${ }^{19}$ A third set of commentators object to the "one-size-fits-all” approach of mandatory shareholder access (e.g., Grundfest 2009). These commentators propose that shareholders should be able to opt-in, or at least opt-out, of the SEC’s proxy access rules.

\footnotetext{
${ }^{19}$ This argument is related to the idea proposed by Burkart, Gromb and Panunzi (1997) that closer oversight may weaken managerial incentives. Adams and Ferreira (2007) argue that management-friendly boards are sometimes optimal because they pose a weaker monitoring threat, which enables them to solicit more information from CEOs.
} 
A recent theory paper by Harris and Raviv (2010) addresses the optimal extent of control to place in the hands of shareholders versus managers. Their model includes strategic communication between self-interested and potentially privately informed managers and shareholders as well as delegation. Harris and Raviv find that when shareholders seek to maximize firm value and are not misinformed, it is optimal to place the delegation decision in the hands of shareholders, allowing them to decide ex ante which decisions to leave to management and which to make directly. Owners will then delegate decisions where management's information advantage outweighs its agency costs to managers. The authors view this result as being consistent with Bebchuk’s (2005) recommendation to allow shareholders to set the "rules of the game" regarding decision power and corporate governance.

A recent paper by Kahan and Rock (2011) argues that proxy access would be unlikely to yield a significant number of shareholder-nominated candidates, and would be unlikely to have a meaningful effect on corporate governance more generally. Drawing inferences from past behavior, the authors argue that neither mutual funds nor private pension funds would make significant use of shareholder access. Large public pension funds "may make some nominations," but hedge funds and union-affiliated funds, which historically have been more activist, would generally not satisfy the ownership and holding period requirements under the Rule. In addition, Kahan and Rock argue that the proxy access rule would not substantially lower the costs of running a short slate contest, and that, in some respects, the costs of running a candidate using the company's proxy statement would be greater than running a candidate in the traditional manner.

While we agree with Kahan and Rock that the number of actual candidates under a shareholder access regime may very well be small, we believe that Kahan and Rock give too 
little weight to the potential for more meaningful "constructive engagement” between large shareholders and the company under a proxy access regime, when the "stick" of a proxy access candidate is lurking in the background. Moreover, Kahan and Rock’s predictions about shareholders' willingness to use proxy access are based on past behavior, and do not account for the possibility that shareholder behavior would change in response to a new regime. ${ }^{20}$ Leaving aside the hypothetical future role of proxy access, our study focuses on a set of investors with a track record of activism (i.e., we study the value changes for firms held by such investors). In any event, we agree with Kahan and Rock that proxy access would have both costs and benefits; the question then becomes how best to predict whether the benefits outweigh the costs, and the magnitude of the net benefits if any.

The idea of empirically evaluating regulatory changes with stock market data was introduced by Schwert (1981). ${ }^{21}$ Two prior studies and one contemporaneous study use this methodology to examine the wealth effects of shareholder proxy access. Akyol, Lim and Verwijmeren (2010) examines 14 events between September 2006 and December 2009 that, in their interpretation, increased ${ }^{22}$ or decreased ${ }^{23}$ the likelihood of shareholder proxy access. For

\footnotetext{
${ }^{20}$ In a recent presentation of this paper at NYU alongside Kahan and Rock, one of us observed that Kahan \& Rock's approach to proxy access could similarly be used to predict that texting is unlikely to be a significant mode of communication: texting is just slightly less costly than e-mail (e.g., no need for a header, as is the convention with email), and in some ways texting is more costly than e-mail (e.g., you need to know the phone number rather than just the e-mail address). Of course, this prediction would be highly inaccurate because behavior has in fact changed in response to the new technology, at least in part because text messages go to a space (the phone number) that is far more sacrosanct than the e-mail in box. The analogy to proxy access should be apparent: a simple cost/benefit analysis ignores the possibility for behavior change due to the fact that a proxy access candidate goes to a "sacred space," namely, the company's own proxy statement.

${ }^{21}$ See Hochberg, Sapienza and Vissing-Jorgensen (2009) for a recent example.

${ }^{22}$ The nine events that, according to the authors, increased the likelihood of shareholder proxy access were: the Second Circuit's holding in AFSCME v. CA (Sept. 5, 2006), the SEC announcement of a roundtable discussion on proxy access (April 24, 2007), the SEC's disclosure of a proposed rule on proxy access (July 27, 2007), a speech by SEC Commissioner Elisse Walter on proxy access (Feb. 18, 2009), a speech by SEC Chairwoman Mary Schapiro on proxy access (April 6, 2009), the SEC's announcement that it would vote on a proposed rule (May 12, 2009), the SEC's announcement of the content of the proposed rule (May 14, 2009), the introduction of the Schumer Bill in the U.S. Senate (May 19, 2009), and the SEC's vote in favor of the proposed rule on proxy access (May 20, 2009).

${ }^{23}$ The five events that, according to the authors, decreased the likelihood of shareholder proxy access were: the SEC's publication of a final Rule 14a-8 with no substantial changes (Nov. 28, 2007), the SEC's publication of a
} 
each event date, they compare the return of a portfolio of U.S. firms to the return of a global market portfolio (excluding U.S. firms) and to a Canadian market portfolio. They also isolate U.S. financial firms from other U.S. firms, on the theory that financial firms might be more likely to be targeted by shareholders for proxy access. Six of the events taken individually produce statistically significant abnormal returns around the event dates (at 95\% confidence), and when the events are aggregated the returns are highly significant and inversely correlated with shareholder proxy access. Specifically, the authors find that an increased likelihood of shareholder access reduced returns to the U.S. portfolio relative to the non-U.S. portfolios, and for U.S. financial firms relative to non-financial U.S. firms. The authors conclude that "increasing shareholder rights ... may actually be detrimental to shareholder wealth," and that the results "highlight the need for the SEC to further deliberate on the proposed rule, and to consider not implementing the proposed changes.”

Larcker, Ormazabal, and Taylor (2010) similarly use an event study approach to examine thirteen events between March 2007 and June 2009 that arguably increased ${ }^{24}$ or decreased ${ }^{25}$ the likelihood of shareholder proxy access. The authors use the number of institutions with $1 \%$ or more ownership (NLargeBlock) and the number of possible coalitions that would control 1\% or

final Rule 14a-8(i)(8) with no substantial changes (Dec. 12, 2007), the introduction of an opt-in shareholder proxy access bill in the Delaware House of Representatives (Mar. 10, 2009), the passage of this bill in the Delaware House (March 18, 2009), the passage of the bill in the Delaware Senate (April 8, 2009), and the reopening of the comment period on the SEC proposed Rule on shareholder access (Dec. 14, 2009).

${ }^{24}$ The eight events that, according to the authors, increased the likelihood of shareholder proxy access are: first mention of the Schumer Bill in the press (April 25, 2009), introduction of the Schumer Bill in the U.S. Senate (May 19, 2009), first mention of the Shareholder Empowerment Act in the press (June 12, 2009), the SEC announcement of a roundtable discussion on proxy access (April 24, 2007), the SEC announcement of amendments to Rule 14a-8 14a-8(i)(8) (July 27, 2007), first mention of potential amendments to Rule 14a-11 (April 6, 2009), the SEC's vote in favor of the proposed rule on proxy access (May 20, 2009), and the publication of the SEC's draft proposal for Rule 14a-11 (June 10, 2009).

${ }^{25}$ The five events that, according to the authors, decreased the likelihood of shareholder proxy access are: the SEC's publication of a final Rule 14a-8 with no substantial changes (Nov. 28, 2007), the SEC's publication of a final Rule 14a-8(i)(8) with no substantial changes (Dec. 6, 2007), the introduction of an opt-in shareholder proxy access bill in the Delaware House of Representatives (Mar. 10, 2009), the passage of this bill in the Delaware House (Mar. 18, 2009), the passage of the bill in the Delaware Senate (April 8, 2009), and the reopening of the comment period on the SEC proposed Rule on shareholder access (Dec. 14, 2009). 
more of the shares outstanding (NSmallCoalitions) as proxies for a company's exposure to a shareholder access rule. For five out of the thirteen events, the authors find a statistically significant (at 95\% confidence) negative correlation between NLargeBlock and events that increased the likelihood of shareholder proxy access. For a (somewhat different) five out of thirteen events, the authors find a statistically significant negative correlation between NSmallCoalitions and events that increased the likelihood of proxy access. As with the Akyol study, the coefficients for both NLargeBlock and NSmallCoalitions become highly significant and inversely correlated with increased likelihood of shareholder access when all thirteen events are pooled. The authors conclude that their findings are consistent with the view that $>1 \%$ shareholders "will use the privileges afforded to them by proxy access regulation to manipulate the governance process to make themselves better off at the expense of other shareholders.” Larcker and Tayan (2010) summarize this literature as suggesting that "regulation of corporate governance is viewed negatively by shareholders.”

One problem inherent in these prior event studies is that at least some of the events being studied are of questionable importance. For example, both the Akyol study and the Larcker study identify the announcement of a SEC roundtable discussion series on April 24, 2007 as an event that increased the likelihood of proxy access. With the SEC having considered proxy access off-and-on for most of the prior decade (and having already promised to take up proxy access after the AFSCME decision the prior year), it is not clear why the announcement of a roundtable discussion - with, of course, no prediction on what conclusions the discussants would reach - should convey meaningful information to the marketplace, much less increase the likelihood of proxy access. 
In fact, the impact of the April 24 announcement on the likelihood of proxy access is not even directionally clear. At the time of the announcement, the AFSCME decision permitted proxy access on a company-by-company basis. In the press release announcing the Roundtable series, SEC Chairman Christopher Cox noted generally: “This roundtable will explore the relationship between the federal proxy rules and state corporation law, and pose questions to the participants about whether this relationship can be improved. ${ }^{26}$ After the Roundtable, the first move from the SEC, proposed in October 2007 and finalized in December 2007, was amendments to Rule 14a-8(i)(8) that overruled the AFSCME decision and eliminated proxy access. To the extent that investors interpreted Cox's general statement to mean that the AFSCME decision was vulnerable (which, in retrospect, would have been an accurate interpretation) the April 24 announcement should have decreased the likelihood of shareholder access, rather than increased it as the Akyrol and Larcker studies predict.

A second potential problem with the Akyrol and Larcker studies is that many of the events were predicted in advance, at least in part, by the marketplace. For example, it is wellknown that the Corporate Law Section of the Delaware Bar Association, not the Delaware legislature, creates Delaware corporate law. Once the Corporate Law Section voted in favor of a shareholder access amendment on February 26, 2009, its implementation in Delaware became virtually a foregone conclusion. Both the Akyol study and the Larcker study examine the introduction of the shareholder access bill in the Delaware House of Representatives (March 10, 2009), the passage of the bill in the House (March 18), and the passage of the bill in the Delaware Senate (April 8), but fail to examine the recommendation from the Corporate Law Council that occurred on February 26. Similarly, the promulgation of the final Rule on August 25,2010 was very accurately predicted in press reports ahead of its actual announcement. If the

\footnotetext{
${ }^{26}$ SEC Announces Roundtable Discussions Regarding Proxy Access, Press Release (April 24, 2007).
} 
marketplace fully anticipates an event, then wealth effects around the event date can be meaningless.

Despite these deficiencies, the Akyol and Larcker studies have led some commentators to conclude that shareholder proxy access reduces shareholder wealth. For example, Grundfest (2010) summarizes the “consistent conclusion” from the two studies as follows:

[P]roxy access, as currently proposed by the Commission, reduces shareholder wealth, and, even if preferred by vocal institutional investors, is inimical to the best interests of the shareholder community as a whole. ... The best currently available empirical data indicate that, given a choice between the current regime and the Commission's proxy access rules, shareholders seeking to maximize returns would prefer the status quo because the proposed rules appear to destroy shareholder wealth.

It should also be noted that both the Akyol and Larcker studies were submitted to the SEC as comment letters during the rulemaking process, and were referenced by the SEC in the final Rule. We find the reliance on these prior event studies to be troubling because many of the events were widely-anticipated, confounded, directionally unclear, and/or not meaningful, for reasons described above. ${ }^{27}$ In contrast, we study a main event that in our view was unanticipated, unconfounded, directionally clear, and highly meaningful with respect to proxy access. Our second event, the Supreme Court ruling in 2011, was predictable but of unknown direction and also directionally clear.

Cohn, Gillan, and Hartzell (2010) also study proxy access using an event study methodology, focusing on firms with activist investors (but using a classification scheme for investors that differs from ours). They use three event dates, all more recent than the Larcker and

\footnotetext{
${ }^{27}$ See also Steven Davidoff, The Heated Debate Over Shareholder Access, NEW YoRK TIMES (Nov. 3, 2010) ("What is remarkable about these arguments is the lack of empirical evidence about the actual effect that proxy access would have on the value of public corporations. That is, there is no scientific evidence either way on the impact that shareholder proxy access will have on the stock prices of public corporations. Will it make these companies more or less valuable? Behind this question is whether proxy access has positive or negative worth. | Until this month, there have only been two empirical studies even purporting to look at these issues.”).
} 
Akyol studies: a refinement of the proxy access rule that clarified the position size requirements for proxy access (June 16-17, 2010); an additional refinement that led to the dropping of the five percent threshold from the Dodd-Frank bill (June 24-25, 2010); and the ultimate passage of the proxy access rule (August 25, 2010). Cohn et al. argue that the $5 \%$ size requirement introduced on June 16/17 was a higher threshold than expected in the marketplace, and therefore should be interpreted as a negative event for proxy access. When this $5 \%$ requirement was dropped on June 24/25 this was, in turn, a positive event for proxy access. On August 25, when the final Rule was announced, Cohn et al. argue that the surprise event was the three-year holding period rather than two years expected by the marketplace; therefore this was a negative event for proxy access. The authors find a positive correlation between proxy access and shareholder wealth, i.e., the two negative events reduced value for companies most vulnerable to proxy access, and the one positive event increased value for companies most vulnerable to proxy access. These findings stand in contrast to the findings from the Akyol and Larcker studies.The Cohn et al paper is similar to this study in that it examines the differential return between firms with and without activist owners. We use different event dates, and sources of the set of activists. Like us, Cohn et al conclude that proxy access appears to have been ascribed positive value by the stock market.

\section{Empirical Strategy}

The unexpected delay that occurred on October 4, 2010 provides the basis for an empirical test of the wealth effects of shareholder access. We apply the idea of Schwert (1981) that stock price changes following the announcement can be informative about the market's 
evaluation of the impact of regulation on value. While our focus is on October 4, 2010, we also examine July 22, 2011, when the D.C. Circuit invalidated proxy access.

For an event to be useful as a natural experiment, there are several requirements. First, it has to be unexpected. By all accounts, the SEC's delay was unexpected, and therefore not predicted in advance by the marketplace. Second, the value impact has to affect stock prices that is, it must be a relatively significant event. The degree of debate and press coverage around shareholder proxy access suggests that implementation of the Rule was a significant event, and, by extension, the delay of the rule was also significant. The fact that the SEC had already implemented shareholder access means that a specific Rule was on the table, and all companies reacted to the same Rule. Finally, evading the proposed regulatory reform must be difficult or impossible. Rule 14a-11 is a mandatory rule, with no prospect for opt-out. For this reason, market prices before October 4 likely did not reflect any possibility that companies might evade the Rule.

If the marketplace perceived that shareholder access would increase shareholder value, then companies that would have been most exposed to the new Rule should decline in value, relative to companies that would have been more insulated from the Rule. If the marketplace perceived that shareholder access would decrease shareholder value, then companies that would have been most exposed to the Rule should increase in value, relative to those that would have been more insulated. Furthermore, we can use the event to test if the perceived value effect of shareholder access depends on the features of a firm or its shareholders. For example, the possibility of board representation may be more valuable when shareholders are sophisticated, or if they are more willing to get involved with the governance of a firm. Board representation may be less valuable if the board already represents the views of outside investors well. 
We use several proxies for determining which companies were more and less likely to be affected by the SEC's proxy access Rule. First, and most importantly, we examine the institutional ownership of the companies in our sample, on the assumption that institutions, particularly institutions that held 3\% or more of the company's stock, would be most likely to make use of proxy access. We also distinguish between activist institutions such as hedge funds, and traditionally passive institutions such as index funds, on the view that activist institutions would be more likely to make use of proxy access. Many institutions are reluctant to exercise control rights and participate in activism (Pozen 2003, Kahan and Rock 2011). Examples include index funds and some pension funds (see e.g. Del Guercio and Hawkins 1999). Other institutions are much more prone to activism and direct influence on corporate governance. For example, Kahan and Rock (2006) argue that hedge funds have stronger financial incentives and fewer regulatory constraints than mutual funds, and may therefore be better able to monitor firms in their portfolios. Greenwood and Schor (2009) also suggest that hedge funds may be better able to identify underperforming companies.

Finally, because the SEC’s Rule would have given proxy access to investors who had held their positions for at least 3 years, we explore empirical specifications that capture the length of time that the firms' existing investors, activist or otherwise, have held their stakes.

We also use three other governance-related measures for determining which companies were more impacted by the SEC's proxy access rule. First, we distinguish between companies incorporated in Delaware and those that are not. At least since May 2009 and likely before, shareholders in Delaware companies have had the ability to opt-in to shareholder access, while shareholders of companies incorporated in other states do not clearly have this right. It seems 
possible, therefore, that Delaware companies would have benefitted less from SEC-mandated shareholder access than companies incorporated in other states.

Finally, we differentiate companies according to whether they have a staggered board, perhaps the most important antitakeover defense (Bebchuk, Coates \& Subramanian 2002), and according to their Governance Index (Gompers, Ishii and Metrick 2003). Both of these measures test the theory that companies with greater entrenchment might be more vulnerable to the SEC's Rule.

The impact of shareholder proxy access may also depend on the scope for improvement in firm performance. A firm with strong current performance and a high stock price may offer fewer opportunities for intervention. We therefore sort firms based on lagged stock returns and valuation ratios, to test whether the impact of institutional and activist institutional ownership is strongest among the firms with the worst recent performance.

Because our empirical results are based on a single event and stock returns have patterns of cross-sectional correlation, our approach and our measures of statistical significance must be adjusted accordingly. Our baseline regressions use risk-adjusted returns, which control for market performance and the two additional risk factors identified in Fama and French (1993) (see the data section for details). Using risk-adjusted returns means that we control for the overall pattern of market movements on October 4. We also report results from using raw returns as the dependent variable for the sake of completeness.

We also need to address cross-sectional correlation among stock returns. Incorrectly assuming independence in stock movements can yield standard error estimates that are biased downward (Fama and French 2000). Therefore, we do not rely on standard regression standard error estimates to assess the significance of our coefficient estimates. Instead, we assess the 
significance of our results in two ways: GLS standard errors and non-parametric assessment using the empirical distribution of coefficient estimates. To calculate GLS standard errors, we follow Greenwood (2005) and use pre-event return data for our sample stocks to estimate the covariance matrix for individual stock returns. We then use the estimated covariance matrix to calculate standard error estimates that adjust for the observed correlations between different stocks. ${ }^{28}$ Applied to this setting, we find GLS standard error estimates are approximately twice as large as OLS standard errors. In all tables reporting regressions, we report the GLS standard errors as well as p-values from the empirical distribution of coefficient estimates.

As a less parametric approach to assessing significance, we re-estimate each regression in the 67 trading days after June 30, 2010. We do not use earlier dates because our key variables of interest are based on institutional holdings as of June 30. We then use the empirical distribution of coefficient estimates to test the significance of each of our regression coefficients. In other words, we empirically estimate how many days other than the event day would have delivered estimated coefficients equal in magnitude to the coefficient we estimate for October 4. Because our significance estimates using this empirical approach are very similar to the GLS-based estimates, our tables report only the GLS standard errors.

\section{Data}

We collect stock price data from Datastream, and define each stock's return as the log of the closing stock price on Monday, October 4, minus the log of the closing stock price on Friday, October 1. We use a one-day event window because the SEC's announcement on delaying

\footnotetext{
${ }^{28}$ In matrix notation, we use $V=\left(X^{\prime} X\right)^{-1}\left(X^{\prime} \Omega X\right)\left(X^{\prime} X\right)^{-1}$ to estimate standard errors, where $\mathrm{X}$ is a vector of return data, and $\Omega$ is the pre-event covariance matrix of returns. This differs from basic OLS standard errors which use the identity matrix in place of $\Omega$. An underlying assumption in this approach is that the pre-event covariance matrix is an appropriate estimate for the true underlying covariance matrix on October 4.
} 
shareholder access came out during the trading day on October $4 .{ }^{29}$ We estimate factor-adjusted returns based on the Fama-French (1993) three-factor model, which controls for firms' exposure to overall stock market movements as well as a value/growth effect and a small firm effect. We estimate firm betas on the Fama-French factors using daily stock returns for the period between January 1, 2009 and December 31, 2009. We use the daily factor returns from Ken French’s data library. ${ }^{30}$ We winsorize all three beta estimates at the $5^{\text {th }}$ and $95^{\text {th }}$ percentiles.

We take the Gompers, Ishii and Metrick (2003) governance measure for each S\&P1500 firm in 2006, the last year for which the index has been calculated. From RiskMetrics, we identify firms with staggered board provisions and collect data on the number of board members. We collect data on each firm's equity value from CRSP; this allows us to run both valueweighted and equal-weighted empirical tests.

Institutional ownership data come from ThomsonReuters, which summarizes data from 13F filings by institutional investors. We use data from the second quarter of 2010, because later data are incomplete. ${ }^{31}$ We look exclusively at shares held by U.S. institutions. For each investment manager, we calculate total holdings, as both dollars and number of stocks. For each firm in the sample we construct the following measures of institutional ownership: the number of institutional owners; the number of institutional owners above the $3 \%$ ownership threshold (the requirement for proxy access under the Rule); a dummy variable equal to 1 if a firm has at least one institutional owner with a 3\% stake; and the total ownership by institutions.

Activist institutional investors are more willing to intervene in corporate governance than institutions overall. Because these investors are particularly aggressive about influencing firm

\footnotetext{
${ }^{29}$ The SEC announcement was time-stamped at 12:21 pm on October 4. The announcement hit Bloomberg at 3:20 pm that day.

${ }^{30}$ See http://mba.tuck.dartmouth.edu/pages/faculty/ken.french/data_library.html. Accessed October 12, 2010.

${ }^{31}$ An earlier draft of the paper used holdings data from the first quarter of 2010.
} 
management and board composition, they are more likely to have made use of proxy access (see e.g. Brav, Jiang, Partnoy, and Thomas 2008). We use the classification of activist investors identified by Greenwood and Schor (2009). They construct a sample of activists based on 13D filings and DFAN filings with the SEC. Investment managers and other investors must file a 13D filling with the SEC within 10 days of acquiring 5\% or more of any class of a company's securities. 13D filings also include a "Purpose of Transaction" section which allows Greenwood and Schor to identify activist purposes and exclude investors whose 13D filings reflect passive strategies. DFAN filings are filed with the SEC by investors intending to engage in a proxy fight with firm management. These filings allow Greenwood and Schor to construct a list of activist investors, which they identify as investors whose 13D or DFAN filings indicate activist intent. They identify 177 investment managers as activists, of which 139 are hedge funds and 38 are non-hedge funds. Many of the activist investors in the Greenwood and Schor sample are serial activists. In particular, eleven hedge funds account for more than two-thirds of the activist activity in the Greenwood and Schor sample. ${ }^{32}$ The Greenwood and Schor classification is narrow in the sense that some activist investors will not appear because they (a) held stakes that were too small to trigger the 13D filing requirement; or (b) the purpose statements may not be accurate, or may become less accurate over time for a given holding (since the filing is done at initial acquisition).

We collect firm data from the CRSP-Compustat merged database. For each firm, we calculate its 2009 end of year book-to-market ratio (book value of common equity divided by the stock price times number of shares outstanding), minus the mean of its Fama-French (48)

\footnotetext{
32 They are: Farallon Capital, Steel Partners, VA Partners, Wynnefield, Blum Capital, Carl Icahn, Chapman Capital, Newcastle Partners, JANA, Third Point, and Pirate Capital.
} 
industry. Similarly, we calculate the industry-adjusted calendar year 2009 stock return using the Fama-French 48-sector industry classification. ${ }^{33}$

\section{$\underline{\text { 5. Results }}$}

Our main sample is the S\&P 1500 because these firms are large, liquid, and heavily traded, but our results also hold for the larger universe of all publicly-traded companies. In the S\&P 1500, we have ownership data for 1,388 firms. Panel A of Table 1 shows the mean institutional ownership as well as activist institutional ownership, both by decile. There is substantial variation in each of these measures. Institutional ownership overall amounts to about half of the typical company's shares, but in the bottom decile, institutional ownership averages about 25.3 percent. In the top decile it averages almost 70 percent. Activist institutional ownership averages $0.05 \%$ of the shares in the bottom decile, but over $13 \%$ of shares in the top decile.

a. Institutional ownership

Panel B of Table 1 presents summary statistics for four measures of institutional ownership: the raw total institutional ownership; the number of owners with at least $3 \%$ of the capital; the highest single activist institutional ownership stake; and the number of activist institutional owners.

Table 2 sorts firms by institutional ownership, and examine returns on October 4 across the different levels of institutional ownership. Figure 1 presents the same information in graphic form. The first column shows that the average equal-weighted return was -124 basis points, but firms in the highest ownership decile dropped 44 basis points more than firms in the lowest ownership decile. The difference is statistically significant at the 1 percent confidence level.

\footnotetext{
${ }^{33}$ Results are similar when we use 12 Fama-French industries, 2-digit NAICS codes, and S\&P Industry sectors.
} 
The next column reports excess returns, which control for firms’ exposure to the market, size, and value factors. Using this return measure, the difference between the returns of high and low institutional ownership stocks is 37 basis points. Sorting on activist owners produces a differential of 43 basis points. Both of these differences are statistically significant.

Table 3 presents the baseline regression results. In column (1), we regress the excess returns for the day of each stock in the S\&P 1500 index on institutional ownership. The coefficient estimate in this specification is -137 basis points, significantly different from zero at the 10 percent confidence level. Here and throughout the paper, our reported standard errors account for the observed correlation of individual stock returns, as discussed in Section 3. The R-squared in this regression is low, reflecting the noisy nature of stock returns and the many factors that will affect individual securities. Although our event clearly affected a subset of firms (i.e. the t-stat is significant), it was not the major mover of stock prices that day (this also applies to the specifications we report below). The coefficient estimate implies that a 10 percentage point increase in institutional ownership was associated with an additional 14 basis point loss of value on October 4. Column (2) of Table 3 presents a similar regression for activist institutions. The estimated coefficients are larger in magnitude and statistically significant at the 1 percent confidence level. The coefficient estimate implies that a ten percentage point increase in activist ownership is associated with a 55 basis point drop in value on October $4 .^{34}$

In columns (3) and (4), we repeat these tests using excess returns. Our excess return measures adjust returns based on the Fama-French three-factor model. Betas for the three-factor model are estimated using daily data from 2009. The coefficient estimate using the comprehensive institutional ownership measure is -113 basis points, again significant at the ten

\footnotetext{
${ }^{34}$ Results using the time window [0,2] or [-1,2], i.e. returns of October 2 and October 5, are similar to baseline results in magnitude and statistical significance. Results with the $[0,3]$ time window which incorporates returns on October 5 and October, 6, are similar in magnitudes but insignificant.
} 
percent level. The coefficient estimate for the activist institutional ownership measure is -527 basis points, significant at the 1 percent confidence level. From this point on, we only report regressions with excess returns. This approach is more conservative, and controls for any differences in factor exposures across stocks. Columns (5) and (6) of Table 3 examine valueweighted excess returns. Coefficient estimates are slightly larger, but the estimated statistical significance falls. ${ }^{35}$

These results are consistent with a loss in value for those firms expected to benefit from proxy access in the future. Are they also consistent with a general loss of faith in SEC enforcement? We believe that they are. However, this does not appear to explain the lower returns for firms that were more likely proxy access targets, since there is no reason that SEC enforcement generally should affect exactly those firms that had high activist ownership. Put differently, we cannot evaluate the extent that the case was perceived as bad news for the SEC's ability to enforce more generally, as long as that effect was market-wide (or affected a different set of firms from those we identified using activist ownership). We cannot extract the market's view of the SEC's general ability to enforce rules.

\section{b. Intra-day returns}

We now turn to intra-day returns to assess the extent to which our 1-day results can be attributed to the SEC's announcement on proxy access. We start with within-day trading data from Bloomberg for all available firms from the S\&P 1500 for October 4, 2010. We divide the trading day into 5-minute windows and calculate for each stock the average trading price during the 5-minute window. We then calculate a cumulative return measure for each 5-minute window

\footnotetext{
${ }^{35}$ If the observed price drop for firms with high activist ownership reflected temporary price pressure as activists dumped their positions, we might expect smaller responses for large institutions since these have deeper and more liquid trading, and can be expected to have smaller price responses to idiosyncratic trading. The fact that the point estimates in the value weighted regress are larger, suggests that we are not necessarily measuring a temporary price movement. We discuss this issue, and try longer time windows to address this concnern, below.
} 
using the change in price from the previous day's close to price observed within that window. We then estimate 79 different regressions of cumulative returns on our activism measure: one for each of the 78 within-day windows and one for the return based on market closing price.

Figure 2 shows the results of our analysis. The aggregate market movement that we document in Table 2 occurs mostly during the morning hours, while the divergence between the activist-owned firms and other firms appears to have come mostly in the afternoon, after the SEC's announcement. The effect appears to have accelerated at the end of the day, after the Bloomberg coverage of the SEC's announcement. This intra-day analysis suggests that our observed activism effect is not a spurious result arising from insufficient control for the overall market movement; in addition, the timing also appears consistent with the hypothesis that the SEC’s announcement caused the underperformance of activist-held firms on October 4, 2010.

\section{c. Alternative specifications}

Table 4 examines alternative measures of institutional ownership. In column (1), we measure the largest institutional stake (as a share of firm equity value), including both activist and non-activist institutions. The estimated coefficient is negative and not statistically significant. Column (2) regresses the October 4 excess return on the largest single activist stake, and our estimated coefficient of -642 basis points is statistically significant at the 1 percent confidence level. The fact that this coefficient is larger than the coefficient for total activist ownership highlights the role of large single activist investors. This is consistent with an important role for concentrated institutional ownership, and may reflect coordination costs or free-riding (see e.g., Grossman and Hart 1980, Shleifer and Vishny 1986).

The third alternative measure is motivated by the details of the SEC's Rule, which would have required an owner to have a 3 percent stake to qualify for proxy access. Although the Rule 
would have allowed investors to combine for the purpose of proxy access, having an individual owner above the 3 percent threshold means that proxy access was feasible without coordination. Having more such owners might increase the likelihood further (this number ranges from zero to four). In column (3), the coefficient on the number of institutional owners with stakes above 3 percent is negative and significant at the 1 percent level. The coefficient estimate implies that each additional large, institutional owner in a firm is associated with a reduction of equity value by 33 basis points on October 4 .

\section{d. Firm heterogeneity}

Having established that activist ownership is associated with negative returns on October 4, we now test hypotheses about the relationship between firm characteristics and the value of proxy access. Table 5 presents the results of this analysis. All of these results use excess return measures, use the S\&P 1500 sample, and control for activist institutional ownership. In general, the evidence of any role for governance metrics is weak.

Our first test looks at the impact of staggered boards, as a proxy for corporate governance at each firm. The regression results in column (1) of Table 5 suggest that having a staggered is not predictive of stock return on the event day. In column (2), we use the Gompers, Ishii and Metrick (2003) governance index (“G”). The hypothesis is that firms with poor governance measures (high $G$ values) may see larger potential benefits from shareholder proxy access. Again, the results are close to zero, and we cannot reject a zero effect at standard confidence levels. $^{36}$

We next turn to Delaware incorporation. Because Delaware corporate law already facilitates opt-in proxy access, the SEC rule might have had a smaller effect for Delaware

\footnotetext{
${ }^{36}$ We have also included the interaction of the GIM index with activist ownership. This interaction is not related to returns, suggesting that the value of the governance index does not mediate the important of proxy access.
} 
companies. ${ }^{37}$ Alternatively, if investors perceived that a proxy access proposal would not be prohibited in other states, notwithstanding their lack of explicit recognition of the possibility of opting in, then Delaware firms should react no differently than firms in other states. We test these competing hypotheses by including the interaction of a dummy for Delaware incorporation and institutional ownership, as well as a dummy variable for Delaware incorporation. The coefficient estimate on the Delaware dummy itself is negative and significant. The interaction of the Delaware dummy with institutional ownership is positive and significant at the 10 percent confidence level. The different coefficients imply that non-Delaware firms saw value drop by 81 basis points for every 10 percentage points of activist ownership, while Delaware-incorporated firms dropped by only 31 basis points per 10 percentage points of activist ownership ( $=0.1^{*}(-$ 810+497) basis points). Thus, the estimated effect of institutional ownership is much smaller for Delaware firms, consistent with our prediction that the marketplaces considers explicit recognition of opt-in proxy access at Delaware firms to be meaningful.

We also examine board structure, specifically, board size. Yermack (1996) argues that smaller boards are more effective than large boards. If this is true, there may be less scope for improvement for firms with small boards, and so the proxy rule announcement return might be larger (i.e., smaller losses for firms that were already well managed). On the other hand, shareholder nominees might have more influence on a smaller board than on a larger board (even though the fraction of directors remains the same, at one-quarter), and so the withdrawn rule might have had more impact on firms with small boards. We test these competing hypotheses for board size in column (4) of Table 5. The coefficient on the board size variable is positive and

\footnotetext{
${ }^{37}$ The same argument would also hold for North Dakota companies, where the corporate law since 2007 has provided mandatory proxy access for any $5 \%$ shareholder that has held their shares for at least two years. See Publicly Traded Corporations Act ch. 102, 2007 N.D. Laws 497, codified at North Dakota Cent. Code § 10-35-08. However, there are no North Dakota firms in the S\&P 1500.
} 
statistically insignificant, indicating that the value loss on October 4 did not depend on board size. $^{38}$

\section{e. Investor heterogeneity: holding periods}

We next examine the effect of institutional holding periods. The proposed SEC Rule would have given proxy access to investors whose stakes had been held for 3 years or more. We thus construct two additional measures of institutional ownership: the first measure (used in columns (2) and (5) of Table 6) is a measure of institutional ownership that includes only the institutional stakes that have been held for more than 3 years. The second measure is based on a weighting scheme, applying a (1/12) weight for holdings held for only 3 months, up through a (12/12) weight to holdings held for 12 quarters. Therefore, the variable puts progressively more weight on holdings that are closer to qualifying under the Rule. Columns (1)-(3) use the baseline measure of institutional ownership, the measure of three year old stakes, and the weighted measure. Columns (4)-(6) we use only activist investors, and apply the same three methods. Coefficient estimates are higher when we use the measures of ownership that control for holding duration, and as before borderline significant for overall institutions, and highly significant for activists. This finding is consistent with the marker reaction on October 4 reflecting holding periods as well as the amount of institutional ownership.

\section{f. Lagged firm performance}

Our final analysis examines the relationship between lagged firm performance and the results we have described above. The scope for improvement by activist investors should vary across firms, and be related to firms’ previous performance. We test this hypothesis by sorting firms based on variables related to recent performance: the end of 2009 book-to-market ratio (the

\footnotetext{
${ }^{38}$ We have replicated this finding with alternative measures of board size, such as the number of directors per million dollars of equity market value (unreported).
} 
ratio of equity book value to market value) and the stock return over 2007-2009. For each of these variables, we demean by Fama-French industry using all firms in the same 48-industry classification. Our assumption is that poor performance relative to a firm's industry is a good proxy for the available scope of potential improvements. Table 7 presents the results of this analysis. Columns (1) and (2) are split by 2007-2009 stock return; columns (3) and (4) are split by market-to-book ratios. ${ }^{39}$ The impact of activist institutional ownership is larger in firms with poor recent performance. The difference between the coefficient estimates in the subsamples is large but insignificant for both splits.

\section{g. The D.C. Circuit decision event date (July 22, 2011)}

We repeat our event study methodology on July 22, 2011, when the D.C. Circuit invalidated the proxy access Rule. Results are reported in Table 8, using 2010Q2 measures of activist holdings, for equal-weighted raw returns, equal-weighted excess returns and valueweighted excess returns for the one day event window of the day of the ruling. The estimate for equal-weighted excess return (the smallest estimate of the three) is -463 basis points, implying that a $10 \%$ difference in activist holdings corresponds to a $4.6 \%$ loss in value on the July 22 . The loss in value for firms with activist owners is therefore slightly smaller on July 22 than on October 4 of the previous year, but directionally similar. To the extent that the court's ruling was a further negative surprise regarding the availability of proxy access going forward, these results are consistent with the results reported with respect to the October 4 event date (that is, companies that were more vulnerable to shareholder proxy access suffered an abnormal decline on that day)The smaller estimated effect might be due to the fact that the July 22 event changed

\footnotetext{
${ }^{39}$ Because we split by whether a firm is above or below average, not median, industry performance, and because we define averages for all Compustat firms, not just the S\&P1500 group, the subsamples are not exactly of equal size. The logic of the test seems to suggest that the best possible split into strong and weak performers is more important than getting equal size samples. Splitting so that samples are equal size provides qualitatively similar results. We have also performed splits into more groups (i.e., quartiles), with similar results.
} 
expectations on proxy access less than the October 4 event. On October 4, the likelihood of proxy access went from virtually $100 \%$ to $0 \%$, at least for 2011 and maybe for longer. On July 22, the likelihood of proxy access went from something substantially less than $100 \%$ to $0 \%$, at least for 2012 and maybe for longer. ${ }^{40}$

\section{Discussion}

We find that the companies that would have been most vulnerable to the SEC's shareholder proxy access rule experienced a statistically significant drop in value after the unexpected delay in the Rule on October 4, 2010. The magnitude of the implied positive effect of proxy access that we find is economically significant. We estimate that firms that would have been most affected by proxy access, as measured by overall institutional ownership, lost 12 basis points of value for each standard deviation of ownership. For firms that had large ownership stakes held by historically activist institutions, the value loss was almost five times as large. The results highlight the importance of the process for nominating and electing directors.

This value loss is particularly striking because the October 4 event only created some probability (less than 1 ) of losing shareholder proxy access. We find a directionally similar, though not statistically significant, drop in shareholder value on July 22, 2011, when the D.C. Circuit invalidated the SEC's proxy access rule. To the extent that the market did not anticipate the D.C. Circuit’s decision, our October 4 results only measure the value loss from delaying shareholder proxy access by one year. That is, the value of shareholder proxy access is likely to be larger than what is captured in our event study.

\footnotetext{
${ }^{40}$ By way of comparison, Bebchuk, Cohen and Wang (2011) found a positive and significant stock market reaction when the Delaware Chancery Court (in effect) unexpectedly weakened staggered boards, and then a negative and statistically significant stock market reaction when the Delaware Supreme Court unexpectedly reversed the Chancery Court decision. The two events in the Bebchuk et al. study operated in opposite directions.
} 
Our findings are consistent with Cohn et al. (2011), which uses three event dates from 2010 (though not October 4). They find that the events that they argue increased the likelihood or impact of shareholder proxy access increased firm equity value, and events that decreased the likelihood or impact of shareholder access decreased firm equity value.

Our findings are inconsistent with Larcker et al. (2010) and Akyol et al. (2010). These prior papers found that events that (arguably) increased the likelihood of shareholder proxy access reduced firm value, and vice versa. The difference between our findings and these prior papers might be explained by time differences. For example, in 2006-09, the market might have had a negative view of shareholder proxy access, but this view might have changed by 2010 . Alternatively, or in addition, in 2006-09, the market did not have clarity on what the final Rule would look like, but by October 2010 the market reacted to a well-defined Rule.

Another possibility that would explain the different findings between our paper and the prior related work might be the different methodologies used, or the nature of the events themselves. For reasons explained in Sections 2-3, we believe that the October 4 event provides the cleanest test on the value of shareholder proxy access because the October 4 event. In our view, the October 4 event, unlike all prior events, was material, directionally clear, and also not expected by the marketplace.

In order to examine the influence of methodological differences, we examined some of the dates proposed in other papers using our methodology: i.e. regressing three-factor excess returns on our measure of activist holdings. In our sample of large firms (S\&P1500), coefficient estimates (the return difference for a one hundred percentage point change in institutional ownership) for June 16-17, 2010; June 24-25, 2010 and August 25, 2010 were 156, 17, and 279 
basis points, respectively. ${ }^{41}$ The t-statistics for these coefficients, using the Greenwood (2005) GLS standard errors, are - $0.78,0.11$ and 1.77 , respectively. In other words, by our methodology, these dates do not deliver significant returns at the $95 \%$ statistical confidence level, a result that is consistent with our view (as discussed in Section 2) that these events were unlikely to have surprised the market. If instead of using the Greenwood (2005) GLS standard errors, we use standard error estimates that do not control for cross-stock correlations, our estimated t-stats become $-1.37,0.17$, and 3.25 , respectively. With these less precise standard errors, one out of three events appears to be statistically significant. When we use raw returns as the dependent variable (i.e. returns that are not adjusted for the impact of broad market movements, as captured by the 3-factor Fama French model), the coefficients and t-statistics (still unadjusted) are 57 ( $\mathrm{t}=6.47), 26(\mathrm{t}=2.48)$ and $-837(\mathrm{t}=2.91)$. Using raw rather than factor-adjusted returns amounts to ignoring the factor and market exposures of activist-held firms, and is not, in our view, an appropriate econometric approach. These differences highlight the importance of addressing econometric concerns related to cross-correlation when dealing with individual stock returns.

Regardless of the underlying explanations for the difference between our findings and the prior work, our paper, along with Cohn et al., challenges the conventional wisdom that the market believed that shareholder access reduced equity values. The causal mechanism for this alternative view is straightforward: enhancing activist investors' voice in corporate governance increases firm value. This value effect was a consistent theme among proponents of the shareholder access Rule during the SEC’s comment period. For example, Roy Katzovicz, general counsel for Bill Ackman's Pershing Square Capital, noted in his comment letter:

Engaged shareholders with meaningful stakes in the companies in which they invest have the potential to regulate corporate conduct through private and market behavior. The existing tools of shareholder engagement, however, have not

\footnotetext{
${ }^{41}$ These dates are included in Cohn et al (2011).
} 
proven to be sufficient or optimally suited for that task. We believe that the SEC's proposal to require public companies to include shareholder nominees in corporate proxy materials goes a long way toward better equipping shareholders to be more effective monitors of corporate behavior and, as a result, another force for good corporate governance. ${ }^{42}$

An alternative interpretation is that activist investors "dumped” shares on October 4. As a starting point in assessing this claim, we find no evidence (in unreported analyses) of abnormal trading volumes on October 4, either overall or at companies that would have been particularly vulnerable to the Rule. Indeed, it would be unusual for an activist investor to have held shares for three years in anticipation of proxy access, and then to have dumped shares within hours when there was a delay in gaining access to this right. But even taking this theory at face value, it would be important to understand why activist investors dumped shares. If they did so because their future voice had been unexpectedly reduced and therefore future cash flows were diminished, then this motivation would be consistent with the conclusion that shareholder access improves firm equity value. If instead activists dumped shares because they would be delayed in their ability to extract private benefits at the expense of other shareholders and the company overall, then this motivation would be consistent with the conclusion that shareholder access reduces firm equity value. As above, our analyses thus far cannot rule out this alternative explanation.

\section{$\underline{\text { 7. Conclusion }}$}

\footnotetext{
${ }^{42}$ http://www.sec.gov/comments/s7-10-09/s71009.shtml. See also Comment Letter from Capital Research and Management (an activist fund with $\$ 775$ billion in assets under management): “As long-term investors actively engaged in voting proxies in the interest of our funds' shareholders, we support a process which allows for meaningful director elections, particularly in cases where corporate boards historically have been unresponsive to investor concerns.”
} 
This paper uses a relatively clean natural experiment to assess the shareholder wealth implications of shareholder proxy access. Contrary to the prior event studies on proxy access, we find significant negative abnormal returns for companies that were most vulnerable to shareholder access on October 4, 2010, when the SEC unexpectedly delayed proxy access for U.S. public companies. We find directionally similar, but slightly smaller, results on July 22, 2011, when the D.C. Circuit ruled in favor of the Business Roundtable. These findings are consistent with the view that financial markets placed a positive value on shareholder access, as implemented in the SEC's 2010 Rule. The difference between our result and earlier work may reflect different methodologies, and in particular the different events used. Our view is that the October 4 announcement makes a particularly useful event for empirical work because it was both material and unexpected.

Our results might be useful to shareholders in determining how to vote on proxy access proposals under the current regime. In addition, because the D.C. Circuit did not reach the Business Roundtable's constitutional challenges, it remains possible that the SEC might propose a new proxy access rule in the future. Prior to the announcement of the D.C. Circuit's decision, the New York Times observed that "the lack of empirical evidence at the time the S.E.C. made its decision will be an issue in the District of Columbia court case.” Our results might contribute to addressing this perceived deficiency if the SEC were to return to the issue of proxy access in the future. 


\section{References}

Adams, Renée, and Daniel Ferreira, 2007, “A Theory of Friendly Boards”, 62(1), February, 217250.

Agrawal, Ashwini K., 2007, 'Corporate Governance Objectives of Labor Union Shareholders,' unpublished working paper.

Akyol, Ali C, Wei Fen Lim and Patrick Verwijmeren, 2010, "Shareholders in the Boardroom: Wealth Effects of the SEC’s Rule to Facilitate Director”, unpublished working paper.

Barclay, Michael J., and Clifford G. Holderness, 1991, "Negotiated Block Trades and Corporate Control”, Journal of Finance, 43(3), July. 861-878.

Bebchuk, Lucian A., John C. Coates IV \& Guhan Subramanian, 2002, “The powerful antitakeover force of staggered boards: theory, evidence, and policy,” Stanford Law Review, 54, 887-951.

Bebchuk, Lucian A. , 2003, “The Case for Shareholder Access to the Ballot”, Business Lawyer 43, 48-64.

Bebchuk, Lucian A., 2005, “The Case for Increasing Shareholder Power”, Harvard Law Review 118: 835-914.

Bebchuk, Lucian A., and Scott Hirst, 2009, "Private ordering and the proxy access debate”, Olin Center for Law, Economics and Business Discussion Paper 653.”

Bebchuk, Lucian, 2007, “The Myth of the Shareholder Franchise”, Virginia Law Review, Vol. 93, No. 3 (May, 2007), pp. 675-732

Bebchuk, Lucian, Alma Cohen and Charles C.Y. Wang, 2011, Staggered Boards and the Wealth of Shareholders: Evidence from a Natural Experiment. Harvard Law School Program on Corporate Governance Working Paper.

Berle, Adolf, and Gardiner Means, 1932, The Modern Corporation and Private Property, Macmillan, New York.

Brav,A., Jiang,W., Partnoy, F. and R. Thomas,2008, “Hedge fund activism, corporate governance and firm performance”, Journal of Finance, 63, 1729-1775.

Burkart, Mike, Denis Gromb and Fausto Panunzi, 1997, "Large Shareholders, Monitoring, and the Value of the Firm”, Quarterly Journal of Economics, Vol. 112, No. 3, August, 693-728.

Cai, Jie, Jacqueline L. Garner and Ralph A. Walkling, 2009, ”Electing Directors”, Journal of Finance, 64(5), 2389-2421.

Cella, Cristina, 2011, “Institutional Investors”, unpublished working paper.

Cohn, Jonathan B., Stuart L. Gillan, and Jay C. Hartzell, 2010, “On the Optimality of Shareholder Control: Evidence from the Dodd-Frank Financial Reform Act,” unpublished working paper.

Del Guercio, Diane, and Jennifer Hawkins, 1999, “The motivation and impact of pension fund activism”, Journal of Financial Economics, 52(3), June, 293-340.

Fama, Eugene F., and Kenneth R. French, 1993, "Common risk factors in the returns on stocks and bond”, Journal of Financial Economics, 32(1), February, Pages 3-56.

Fama, Eugene F., and Kenneth R. French, 2000, “Forecasting Profitability and Earnings”, The Journal of Business, 73 (2), April, pp. 161-175.

Gillan, Stuart L. and Laura T. Starks, 2000, “Corporate governance proposals and shareholder activism: the role of institutional investors,” Journal of Financial Economics 57, pp. 275305. 
Gompers, Paul A., Joy L. Ishii, and Andrew Metrick, 2003, “Corporate governance and equity prices”, Quarterly Journal of Economics, 118, 107-155.

Greenwood, Robin, 2005, "Short- and long-term demand curves for stocks: theory and evidence on the dynamics of arbitrage”, Journal of Financial Economics, 75(3), March, 607-649.

Greenwood, Robin, and Michael Schor, 2009, “Investor Activism and Takeovers”, Journal of Financial Economics 92: 362-375

Grossman, Sanford J., and Oliver Hart, 1980, Takeover Bids, the Free-Rider Problem, and the Theory of the Corporation”, Bell Journal of Economics, 11, 42-64

Grundfest, Joseph A., 2009, “The SEC's Proposed Proxy Access Rules: Politics, Economics, and the Law”, Business Lawyer, 65(2), February.

Grundfest, Joseph A., 2010, "Measurement Issues in the Proxy Access Debate”, working paper.

Harris, Milton, and Artur Raviv, 2010, "Control of Corporate Decisions: Shareholders versus Management”, Review of Financial Studies, forthcoming.

Hermalin, Benjamin E., and Michael S. Weisbach, 1998, “Endogenously Chosen Boards of Directors and Their Monitoring of the CEO”, American Economic Review, 1998, March, 88(1).

Hermalin, Benjamin E., and Michael S. Weisbach, 2003, "Boards of Directors as an Endogenously Determined Institution: A Survey of the Economic Literature”, FRBNY Economic Policy Review, April.

Hochberg, Yael V. , Paola Sapienza and Annette Vissing-Jørgensen, 2009, “A Lobbying Approach to Evaluating the Sarbanes-Oxley Act of 2002”, Journal of Accounting Research, Blackwell Publishing, vol. 47(2), pages 519-583, 05.

Holderness, Clifford G., and Dennis P. Sheehan, 1985, "Raiders or Saviors? The Evidence on Six Controversial Investors”, Journal of Financial Economics, 14, 555-579.

Jensen, Michael, 1993, “The modern industrial revolution, exit, and the failure of internal control systems”, Journal of Finance 48, 831-880.

Kahan, Marcel, and Edward Rock, 2011, “The insignificance of proxy access”, Virginia Law Review, 97, 1347-1434.

Kahn, Charles, and Andrew Winton,1998, “Ownership Structure, Speculation, and Shareholder Intervention” Journal of Finance.

Larcker, David F., Gaizka Ormazabal, and Daniel J. Taylor, 2010, “The Market Reaction to Corporate Governance Regulation”,Journal of Financial Economics (forthcoming).

Larcker and Tayan (2010). Proxy Access: A Sheep, or Wolf in Sheep's Clothing, Stanford Business School Note.

Lipton, Martin, and Steven A. Rosenblum, 2003, “Election Contests in the Company’s Proxy: An Idea Whose Time Has Not Come”, Business Lawyer 67.

Pozen, Robert C., 2003, “Institutional Perspective on Shareholder Nominations of Corporate Directors”, Business Law, 95.

Schwert, W. G., 1981, “Using financial data to measure effects of regulation”, Journal of Law and Economics 24, 121-158.

Shleifer, Andrei, and Robert Vishny, 1986, “Large shareholders and corporate control”, Journal of Political Economy 94, 461-488.

Shleifer, Andrei, and Robert W. Vishny , 1997, “A Survey of Corporate Governance”, Journal of Finance, 52(2), pp. 737-783.

Yermack, David, 1996, "Higher market valuation of companies with a small board of directors", Journal of Financial Economics, 40 (2), February, 185-211. 
Figure 1.October 4 returns by institutional ownership decile

The graphs show equal-weighted returns in basis points for firms in each decile of institutional ownership or activist institutional ownership. 95\% confidence intervals are plotted around each mean return, assuming independence. Returns outside of $[-0.3,0.3]$ are excluded.

Panel A. Raw returns, institutional ownership deciles

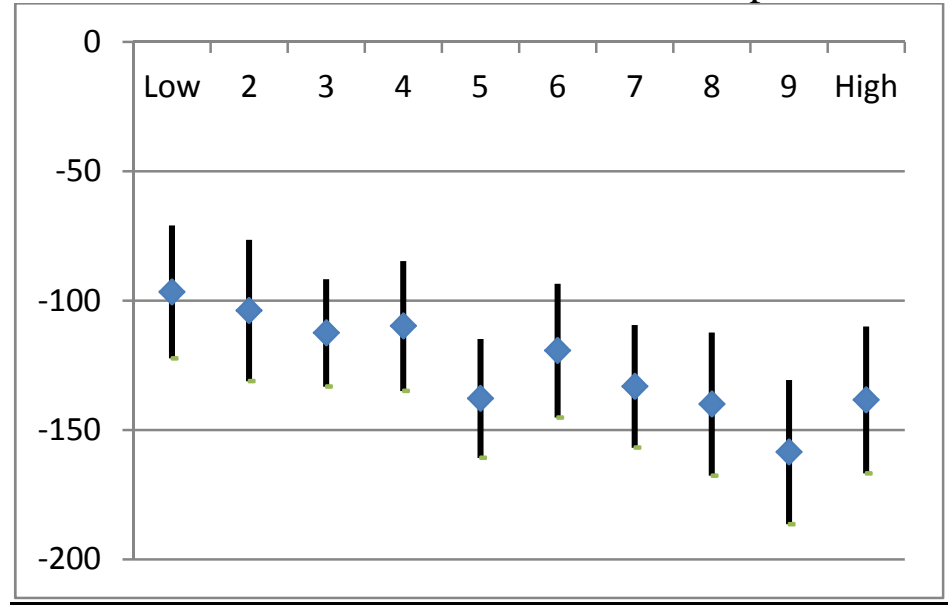

Panel B. Excess returns, institutional ownership_deciles

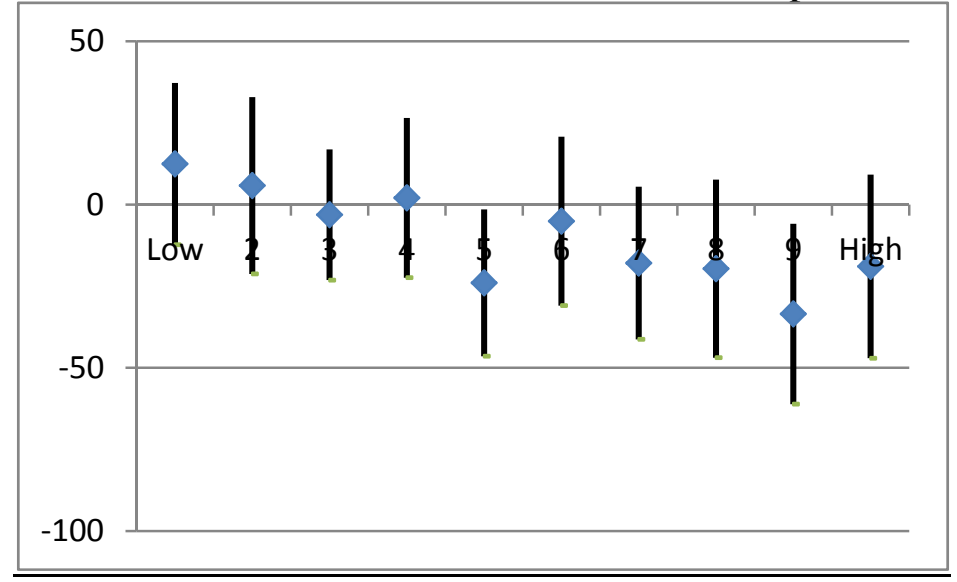

Panel C. Excess returns, activist institutional ownership deciles 


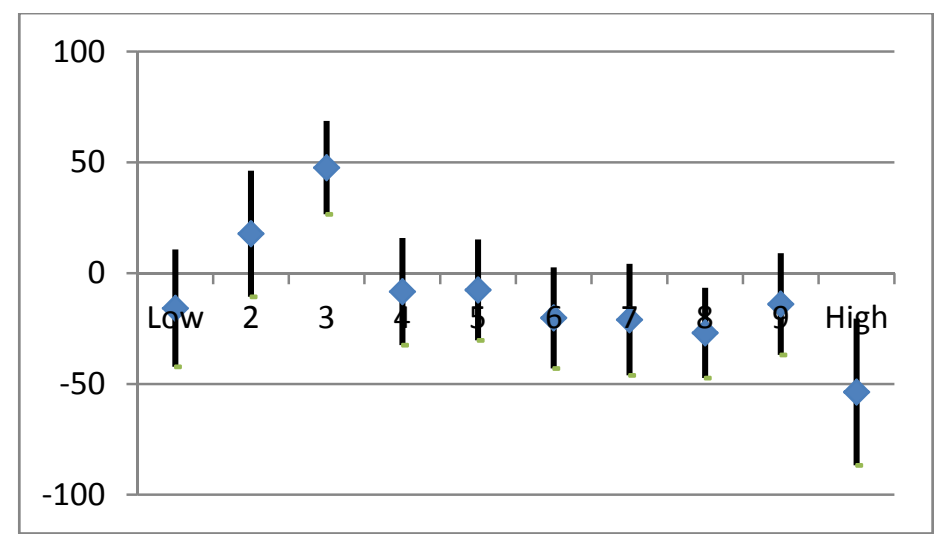

Figure 2. October 4 intraday returns

This graph shows cumulative returns relative to closing price on Friday, October 1, for 5 minute intervals throughout the trading day on October 4, in basis points. The return is calculated using trade-level data from Bloomberg. The dashed line shows the equal-weighted average return for S\&P1500 firms for each period. The solid line shows the regression coefficient on activist ownership. The timing of key news events is indicated with shaded vertical lines.

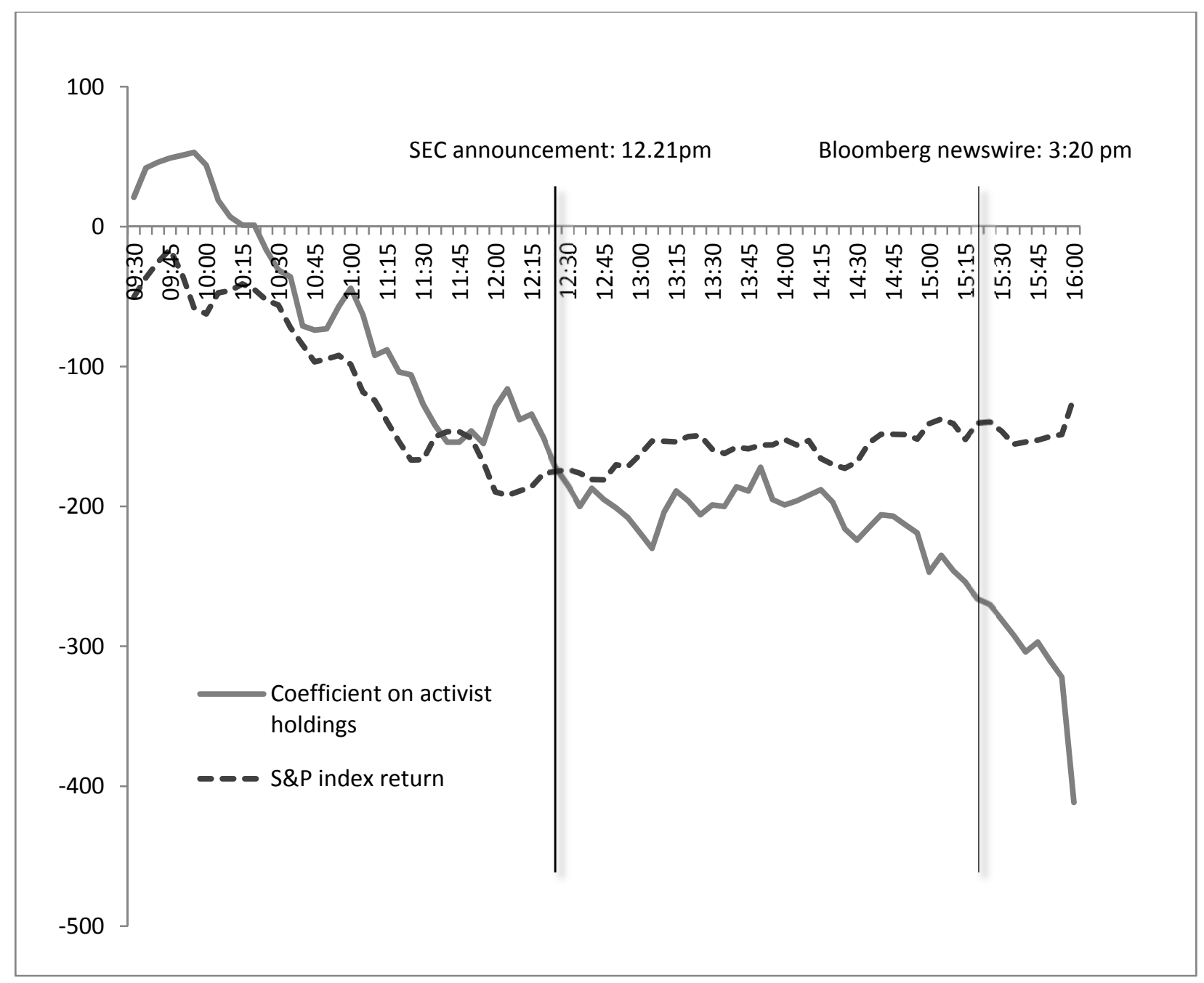




\section{Table 1. Institutional ownership}

This table summarizes the institutional ownership data for all firms in the S\&P 1500 index. Returns outside of [-0.3, 0.3] are excluded. Ownership data is based on June, 2010 13(f) filings. Panel A reports average ownership by decile. Panel B reports summary statistics for various measures of institutional ownership

Panel A

\begin{tabular}{cccc} 
Decile & $\begin{array}{c}\text { Activist } \\
\text { Institutional ownership } \\
\text { (June 2010), mean }\end{array}$ & $\begin{array}{c}\text { institutional } \\
\text { ownership (June } \\
\text { 2010), mean }\end{array}$ & Firms \\
\hline \hline 1 & $25.3 \%$ & $0.05 \%$ & 139 \\
2 & $37.9 \%$ & $0.32 \%$ & 138 \\
3 & $42.1 \%$ & $0.77 \%$ & 140 \\
4 & $45.4 \%$ & $1.33 \%$ & 139 \\
5 & $48.4 \%$ & $1.98 \%$ & 138 \\
6 & $51.0 \%$ & $2.63 \%$ & 139 \\
7 & $53.7 \%$ & $3.57 \%$ & 138 \\
8 & $56.9 \%$ & $4.89 \%$ & 139 \\
9 & $61.3 \%$ & $7.40 \%$ & 138 \\
10 & $69.6 \%$ & $13.20 \%$ & 139 \\
\hline All & $49.2 \%$ & $3.60 \%$ & 1,388
\end{tabular}

\section{Panel B}

\begin{tabular}{lcccccc} 
Variable & Mean & Std dev & $\begin{array}{c}10 \text { th } \\
\text { percentile }\end{array}$ & Median & $\begin{array}{c}90 \text { th } \\
\text { percentile }\end{array}$ & $\begin{array}{c}\text { Observati } \\
\text { ons }\end{array}$ \\
\hline \hline Institutional ownership, all & $49.1 \%$ & $12.6 \%$ & $35.0 \%$ & $49.8 \%$ & $64.4 \%$ & 1,388 \\
Institutional ownership, activists & $3.6 \%$ & $4.0 \%$ & $0.1 \%$ & $2.3 \%$ & $9.1 \%$ & 1,388 \\
Number of activist owners with at & 0.32 & 0.57 & 0 & 0 & 1 & 1,388 \\
least 3\% & $2.52 \%$ & $3.10 \%$ & $0.12 \%$ & $1.40 \%$ & $6.69 \%$ & 1,388 \\
Highest activist stake & & & & & &
\end{tabular}




\section{Table 2. Stock returns Monday, October 4, by institutional ownership}

This table reports stock returns for S\&P1500 firms by institutional ownership or activist institutional ownership decile for Monday, October 4, 2010. Returns outside of [-0.3, 0.3] are excluded. Return data is from Datastream, and measured in basis points. Excess return is the residual after regressing returns on betas from the Fama-French three factor model, with betas estimated over the first six months of 2010. Weighted average return is weighted by market capitalization using outstanding shares of the first quarter 2010, from CRSP.

\begin{tabular}{ccccc} 
Decile & $\begin{array}{c}\text { Equal weighted } \\
\text { return, all } \\
\text { institutions }\end{array}$ & $\begin{array}{c}\text { Equal } \\
\text { weighted } \\
\text { excess return, } \\
\text { all institutions }\end{array}$ & $\begin{array}{c}\text { Equal } \\
\text { weighted } \\
\text { excess return, } \\
\text { activist owners }\end{array}$ & Observations \\
\hline \hline Low & -95.4 & 12.5 & -17.9 & 139 \\
2 & -96.2 & 9.9 & 14.1 & 138 \\
3 & -112.6 & -6.3 & 47.1 & 140 \\
4 & -108.2 & 2.0 & -11.9 & 139 \\
5 & -136.7 & -26.7 & -15.7 & 138 \\
6 & -122.7 & -11.3 & -16.8 & 139 \\
7 & -134.9 & -23.3 & -18.9 & 138 \\
8 & -140.7 & -23.8 & -31.8 & 139 \\
9 & -157.8 & -37.6 & -17.6 & 138 \\
High & -139.3 & -24.4 & -60.4 & 139 \\
\hline Average & -124.4 & -10.2 & -12.9 & 1,388 \\
Difference: $10-1$ & -43.9 & -36.9 & -42.5 & \\
Difference: $10 / 9-1 / 2$ & -52.8 & -42.2 & -37.1 &
\end{tabular}




\section{Table 3. Regressions of excess stock returns Monday, October 4}

The table reports regression of stock returns for October 4, on various controls. Return data is form Datastream, and measured in basis points. Returns outside of $[-0.3,0.3]$ are excluded. Excess return is the residual after estimating a Fama-French three factor model. Columns (5) and (6) use weighted returns based on market capitalization, defined using outstanding shares of the first quarter 2010, from CRSP. Institutional ownership is measured in June 2010. Standard errors allow for cross-sectional correlation. $*=$ statistically significant at $90 \%$ confidence; $* *=95 \%$ confidence; $* * *=99 \%$ confidence.

\begin{tabular}{|c|c|c|c|c|c|c|}
\hline \multirow[t]{2}{*}{ Returns } & \multicolumn{2}{|c|}{ Raw, EW } & \multicolumn{2}{|c|}{ Excess, EW } & \multicolumn{2}{|c|}{ Excess, VW } \\
\hline & (1) & (2) & (3) & (4) & (5) & (6) \\
\hline Institutional ownership & $\begin{array}{c}-136.6^{*} \\
(72.7)\end{array}$ & & $\begin{array}{c}-112.9 * \\
(60.7)\end{array}$ & & $\begin{array}{l}-170.3 \\
(112.6)\end{array}$ & \\
\hline $\begin{array}{l}\text { Activist institutional } \\
\text { ownership }\end{array}$ & & $\begin{array}{c}-553.2 * * * \\
(189.8)\end{array}$ & & $\begin{array}{c}-527.3 * * * \\
(161.8)\end{array}$ & & $\begin{array}{l}-601.8^{*} \\
(323.9)\end{array}$ \\
\hline Constant & $\begin{array}{c}-57.3 \\
(168.4)\end{array}$ & $\begin{array}{l}-104.5 \\
(172.9)\end{array}$ & $\begin{array}{c}42.6 * * \\
(36.8)\end{array}$ & $\begin{array}{c}6.1 \\
(26.7)\end{array}$ & $\begin{array}{l}-7.2 \\
(6.5)\end{array}$ & $\begin{array}{c}13.2 \\
(37.2)\end{array}$ \\
\hline R-squared & 0.010 & 0.020 & 0.006 & 0.018 & 0.006 & 0.004 \\
\hline $\mathrm{N}$ & 1,388 & 1,388 & 1,388 & 1,388 & 1,388 & 1,388 \\
\hline
\end{tabular}




\section{Table 4. Regressions of excess stock returns Monday, October 4}

This table reports regression of stock returns for October 4, on various controls. Return data is form Datastream, and measured in basis points. Returns outside of $[-0.3,0.3]$ are excluded. Excess return is the residual after estimating a Fama-French three factor model. Intercepts are included but not reported. Standard errors allow for cross-sectional correlation. $*=$ statistically significant at $90 \%$ confidence; $* *=95 \%$ confidence; $* * *=99 \%$ confidence.

(1)

Largest institutional stake

Largest institutional stake, activist

Number of activist institutional owners above 3\%

R-squared

$\mathrm{N}$
$-110.3$

(159.5)

(2)

(3)

$-642.3 * * *$

(220.5)

$-32.9 * * *$

$\begin{array}{lll}0.001 & 0.017 & 0.015 \\ 1,388 & 1,388 & 1,388\end{array}$




\section{Table 5. Regressions of excess stock returns Monday, October 4 on firm characteristics}

The table reports regression of stock returns for October 4, on various controls. Return data is form Datastream, and measured in basis points. Excess return is the residual after estimating a Fama-French three factor model. Returns outside of [-0.3, 0.3] are excluded. Only S\&P 1500 firms are included. Institutional ownership is measured in June 2010. Staggered board is a dummy equal to one if the board is classified. G-index is the governance index of Gompers, Ishii and Metrick (2003), based on 2006 (the last date for which the components are reported). Delaware incorporation is a dummy equal to 1 if the firm is incorporated in Delaware. Board size is the log of the number of board members. Intercepts are included but not reported. Standard errors allow for cross-sectional correlation. * $=$ statistically significant at $90 \%$ confidence; $* *=95 \%$ confidence; $* * *=99 \%$ confidence.

(1)

Activist institutional ownership

$-526.8^{* * *}$

Staggered board dummy

G-index

Delaware incorporation

Delaware * Act. inst'l

ownership

Board size

\section{(2)}

$-461.1 * *$

(186.4)

R-squared

$\mathrm{N}$
0.014

1,388

(3)

$-810.4^{* * *}$

(241.4)

(4)

$-502.3^{* * *}$

(157.8)

\section{4)}

**




\section{Table 6. Regressions of excess stock returns Monday, October 4: length of holdings}

The table reports regression of stock returns for October, 4, on various controls. Return data is form Datastream, and measured in basis points. Returns outside of $[-0.3,0.3]$ are excluded. Excess return is the residual after estimating a Fama-French three factor model. Only S\&P 1500 firms are included. Institutional ownership is measured for each of the twelve quarters ending in June 2010. Intercepts are included but not reported. Standard errors allow for cross-sectional correlation. $*=$ statistically significant at $90 \%$ confidence; $* *=95 \%$ confidence; $* * *=99 \%$ confidence.

$(1)$ $-112.9 *$

Institutional ownership

(60.7)

Institutional ownership, three year old positions only ${ }^{\text {a }}$

Institutional ownership, holding period weighted ${ }^{b}$

Activist institutional ownership

Activist institutional ownership, three year old positions only ${ }^{\text {a }}$

Activist institutional ownership, holding period weighted ${ }^{\mathrm{b}}$

R-squared

$\mathrm{N}$

0.008

1,388
(2)

(3)

(4)

(5)

(6)

\section{$-198.6^{* *}$}

\section{$-527.3 * * *$}

(161.8)

\section{$-735.6 * * *$}

$(276.0)$

$-711.7 * * *$

(229.7)

0.017

1,388

${ }^{\text {a }}$ Measure of institutional ownership includes only positions held continuously for three years.

${ }^{\mathrm{b}}$ Measure of institutional ownership weights holdings according to duration continuously held: (1/12) weight for positions held for 1 quarter, (2/12) weight for positions held for 2 quarters, up to (12/12) weight for positions continuously held for three years. 


\section{Table 7. Regressions of excess stock returns Monday, October 4: by subsamples of industry-adjusted performance}

The table reports regression of stock returns for October, 4, on various controls. Return data is form Datastream, and measured in basis points. Returns outside of $[-0.3,0.3]$ are excluded. Excess return is the residual after estimating a Fama - French three factor model. Only S\&P 1500 firms are included. Institutional ownership is measured in June 2010. All performance is measured relative to the mean for the Fama-French (48) industry to which the firm belongs. The cut-off between "HIGH" and "LOW" is zero. Intercepts are included but not reported. Standard errors allow for cross-sectional correlation. * = statistically significant at $90 \%$ confidence; $* *=95 \%$ confidence; $* * *=99 \%$ confidence.

\begin{tabular}{lcccc} 
& $\begin{array}{c}2007-2009 \\
\text { stock return is } \\
\text { LOW }\end{array}$ & $\begin{array}{c}2007-2009 \\
\text { stock return is } \\
\text { HIGH }\end{array}$ & $\begin{array}{c}\text { Book-to- } \\
\text { market is } \\
\text { HIGH }\end{array}$ & $\begin{array}{c}\text { Book-to- } \\
\text { market is } \\
\text { LOW }\end{array}$ \\
\hline \hline Activist institutional ownership & $(1)$ & $(2)$ & $(3)$ & $(4)$ \\
& $-682.1^{* *}$ & $-463.0^{* *}$ & -172.6 & $-442.0^{* * *}$ \\
& $(277.0)$ & $(176.0)$ & $(308.7)$ & $(167.2)$ \\
& & & & \\
R-squared & 0.025 & 0.018 & 0.025 & 0.013 \\
$\mathrm{~N}$ & 432 & 909 & 264 & 1,096 \\
\hline
\end{tabular}




\section{Table 8. Regressions of excess stock returns July 22, 2011}

The table reports regression of stock returns for July 22, on various controls. Return data is form Datastream, and measured in basis points. Returns outside of [0.15, 0.15] are excluded. Excess return is the residual after estimating a Fama-French three factor model. Column (3) uses weighted returns based on Market capitalization, defined using outstanding shares of the first quarter 2010, from CRSP. Institutional ownership is measured in June 2010. Intercepts are included but not reported. Standard errors allow for cross-sectional correlation. $*=$ statistically significant at $90 \%$ confidence; $* *=95 \%$ confidence; $* * *=99 \%$ confidence.

\begin{tabular}{lccc} 
Returns & $\begin{array}{c}\text { Raw, EW } \\
(1)\end{array}$ & $\begin{array}{c}\text { Excess, EW } \\
(2)\end{array}$ & $\begin{array}{c}\text { Excess, VW } \\
(3)\end{array}$ \\
\hline \hline & & & \\
Activist institutional ownership & $-490.7^{* * *}$ & $-463.3^{* * *}$ & $-667.0^{* *}$ \\
& $(139.6)$ & $(128.6)$ & $(317.9)$ \\
& & & \\
R-squared & & & \\
N & & & 0.011 \\
& 0.009 & 0.008 & 1,389
\end{tabular}

